\title{
Tahu yang Difermentasi Rhizopus sp. Menurunkan Kadar Glukosa Darah Tikus Putih(Rattus norvegicus)
}

\author{
Eldaa Putik Bunga Melati ${ }^{1}$, Budiyanti Wiboworini' ${ }^{2}$, Briandani Subariyanti ${ }^{2}$
}

1. Program Studi Kedokteran, Fakultas Kedokteran Universitas Sebelas Maret

2. Departemen Gizi Fakultas Kedokteran Universitas Sebelas Maret

Korespondensi : bwiboworini@gmail.com

\begin{abstract}
ABSTRAK
Latar Belakang: Banyaknya komplikasi yang dapat timbul dari diabetes melitus (DM) menyebabkan pengendalian kadar glukosa darah menjadi sangat penting. Salah satu cara mempertahankan kadar glukosa darah normal adalah dengan pola makan dengan serat yang cukup. Asupan serat salah satunya terdapat di dalam tahu yang difermentasi dengan Rhizopus sp.Penelitian ini bertujuan untuk mengetahui adanya pengaruh pemberian tahu yang difermentasi dengan Rhizopus sp. terhadap kadar glukosa darah puasa tikus putih (Rattus norvegicus) yang dibuat diabetik.

Metode : Penelitian ini bersifat eksperimental laboratorik. Subyek adalah Rattus norvegicus yang dipilih secara random. Subyek berjumlah 30 ekor disuntikkan Alloxan dengan dosis $15 \mathrm{mg} / 100$ gramBB, lalu dibagi kedalam 5 kelompok, yaitu kontrol positif (glibenklamid 0,05 mg/100gramBB/hari), kontrol negatif (aquadest), kelompok perlakuan diberikan tahu yang difermentasi dengan Rhizopus sp. dosis $0,025 \mathrm{gram} / 100$ gramBB/hari; 0,050gram/100 gramBB/hari; dan 0,100gram/ 100 gramBB/hari). Rancangan yang digunakan dalam penelitian ini adalah Pretest and Posttest Control Group Design. Pengukuran glukosa darah puasa dilakukan sebelum pemberian aloksan (hari ke-2), setelah pemberian Alloxan (hari ke-4), dan setelah perlakuan (hari ke-18).

Hasil : Terdapat penurunan kadar glukosa darah puasa secara signifikan pada semua kelompok perlakuan dan kontrol positif $(\mathrm{p}=0,001)$. Post Hoc Test menunjukkan perbedaan bermakna kelompok kontrol negatif dibandingkan dengan semua kelompok perlakuan dan kelompok kontrol positif $(\mathrm{p}=0,001)$.

Simpulan: Tahu yang difermentasi dengan Rhizopus sp. dapat menurunkan kadar glukosa darah tikus putih (Rattus norvegicus) yang dibuat diabetik.
\end{abstract}

Kata Kunci: tahu yang difermentasi dengan Rhizopus sp., kadar glukosa darah, , alloxan, glibenklamid

\section{ABSTRACT}

Introductions : Controlling of blood glucose would be important to prevent many complications of DM. Consuming fiber is one way to maintain blood glucose level. These amount of fiber could be obtained in tofu fermented by Rhizopus sp. This research aimed to know the effect of tofu fermented by Rhizopus sp. in controlling blood glucose level of diabetic induced white rats (Rattus norvegicus).

Methods : This research was a laboratoric-experimental study. The subjects were Rattus norvegicusgrouped randomly. The total 30 Rattus norvegicus were injected by Alloxan $15 \mathrm{mg} / 100 \mathrm{gramBW}$, then randomly allocated into 5 group, positive control group (glibenclamide $0.05 \mathrm{mg} / 100$ gramBW/day), negative control group (aquadest), and treatment groups with different doses of fermented tofu $(0.025 \mathrm{gram} / 100 \mathrm{gramBW} /$ day; 
$0.050 \mathrm{gram} / 100 \mathrm{gramBW} /$ day; $0.100 \mathrm{gram} / 100 \mathrm{gramBW} /$ day). The research design was Pretest and Posttest Control Group Design. The fasting blood glucose were measuredbefore Alloxan injection (day-2), after Alloxan injection (day-5), and after the treatments (day-19).

Results : there was a significant decrease of blood glucose level in all treatment groups and positive control $(p=0.001)$. Post Hoc Test showed a significant difference between all treatment groups and positive control group compared to negative control group ( $p$ $=0.001$ ).

Conclusion :Tofu fermented by Rhizopus sp. was able to decrease blood glucose level in diabetic rats (

Keyword : Tofu fermented, Rhizopus sp., blood glucose level, alloxan, glibenclamide

\section{PENDAHULUAN}

Diabetes melitus (DM) merupakan penyakit kronik yang diperkirakan jumlahnya akan terus meningkat. DM ditandai dengan kadar glukosa dalam darah yang tinggi atau disebut sebagai hiperglikemia ${ }^{1}$. Glukosa tidak dapat masuk ke dalam sel, tertahan dalam pembuluh darah dan tidak dapat diubah menjadi energi. Asupan energi yang melebihi kebutuhan terutama yang berasal dari karbohidrat dapat berpengaruh pada peningkatan kadar glukosa darah ${ }^{2}$.

Hiperglikemia mempengaruhi kesehatan seseorang dan komplikasi yang menyertainya, baik komplikasi mikrovaskular maupun makrovaskular ${ }^{3}$. Komplikasi yang dapat terjadi antara lain adalah retinopati diabetik, nefropati diabetik, dan neuropati diabetik. Komplikasi-komplikasi tersebut menyebabkan pengendalian kadar glukosa darah menjadi sangat penting untuk dilakukan ${ }^{4}$

Kadar glukosa darah dalam tubuh seseorang bervariasi karena dipengaruhi oleh beberapa faktor, misalnya usia, jenis kelamin, faktor genetik, emosi, stress, dan pola makan ${ }^{5}$. Terdapat dua kriteria yang digunakan untuk menyatakan nilai kadar glukosa darah yang baik, yaitu kadar glukosa darah puasa 80 $<100 \mathrm{mg} / \mathrm{dL}$ dan 2 jam setelah makan 80-144 $\mathrm{mg} / \mathrm{dL}^{6}$.

Penelitian sebelumnya menyatakan bahwa glukosa darah pada penderita diabetes melitus dapat turun dan lebih stabil dengan konsumsi serat yang dilakukan selama 6 minggu ${ }^{7}$.Konsumsi serat dapat mempengaruhi respon hormon insulin dan mengurangi beban kerja pankreas ${ }^{8}$.

Serat dapat menurunkan penyerapan glukosa di usus sehingga kadar glukosa darah ikut menurun. Salah satu tambahan asupan serat ini dapat diberikan dalam bentuk tahu yang difermentasi dengan Rhizopus sp. Tahu yang difermentasi dengan Rhizopus sp. juga mengandung asam omega-3, isoflavon, dan protein. Isoflavon dan protein diketahui dapat meningkatkan sensitivitas insulin, sementara asam omega-3membantu meningkatkan penyimpanan glukosa ke dalam otot untuk mengontrol kadar glukosa darah ${ }^{9,10,11}$. Tujuan penelitian ini adalah untuk mengetahui adanya pengaruh pemberian tahu yang difermentasi dengan Rhizopus sp. terhadap kadar glukosa darah puasa tikus putih (Rattus norvegicus) yang diinduksi Alloxan.

\section{METODE}

Penelitian ini dilakukan di Laboratorium Farmakologi Universitas Setia Budi Surakarta dengan rancangan eksperimental laboratorik dan pendekatan Pretest and Posttest Control Group Design.Subyek pada penelitian adalah Rattus norvegicus yang dipilih secara random dengan berat \pm 200 gram dan berjumlah 30 ekor. Subyek disuntikkan Alloxan dengan dosis $15 \mathrm{mg} / 100$ gramBB, lalu dibagi secara acak kedalam 5 kelompok dengan perlakuan berbeda, yaitu kontrol positif (glibenklamid 0,05 $\mathrm{mg} / 100 \mathrm{gramBB} /$ hari), kontrol negatif 
(aquadest), kelompok perlakuan dengan tahu yang difermentasi dengan Rhizopus sp. dengan dosis 0,025 gram $/ 100$ gramBB/hari; 0,050 gram $/ 100$ gramBB/hari; dan 0,100 gram/100gramBB/hari).

Pengukuran glukosa darah puasa dilakukan sebelum pemberian Alloxan (hari ke-2), tiga hari setelah pemberian aloksan (hari ke-5), dan setelah perlakuan (hari ke19). Variable bebas adalah pemberian tahu yang difermentasi dengan Rhizopus sp. Variabel terikat adalah kadar glukosa darah tikus putih (Rattus norvegicus). Instrumen yang digunakan dalam penelitian ini meliputi kandang hewan uji, tabung mikrohematokrit, neraca elektronik, alat pencekok oral, pakanpelet, aquadest, tahu yang difermentasi dengan Rhizopus sp., Alloxan, dan GlucoDr Blood Glucose Meter untuk mengukur kadar glukosa darah. Data yang diperoleh dari hasil penelitian kemudian di analisis dengan One Way ANOVA dan dilakukan Post Hoc Test untuk membandingkan hasil yang diperoleh.

\section{HASIL}

Sebelum perlakuan didapatkan nilai $\mathrm{p}$ $=0,861$ untuk kadar glukosa darah tikus putih (Rattus norvegicus) yang menyatakan bahwa tidak terdapat perbedaan yang signifikan pada kadar gula darah tikus putih (Rattus norvegicus) sebelum injeksi Alloxan (GD1). Setelah injeksi Alloxan (GD2) terjadi peningkatan kadar glukosa darah tikus putih (Rattus norvegicus), dengan nilai $\mathrm{p}=0,827$ yang menyatakan bahwa peningkatan kadar gula darah tidak menunjukan perbedaan yang signifikan secara statistik. Tabel 1 menunjukkan setelah adanya perlakuan (GD3) didapatkan nilai $\mathrm{p}=0,000$, yang berarti bahwa terdapat perbedaan yang signifikan antara kelompok perlakuan secara bersama-sama.

\begin{tabular}{llll}
\hline Kelompok & $\begin{array}{l}\text { Sebelum } \\
\text { Perlakuan } \\
(\text { Hari ke 2) } \\
(\mathrm{GD} 1) \\
(\mathrm{mg} / \mathrm{dl})\end{array}$ & $\begin{array}{l}\text { Setelah } \\
\text { Pemberian } \\
\text { Aloksan } \\
\text { (hari Ke }-4) \\
(\mathrm{GD} 2)(\mathrm{mg} / \mathrm{dl})\end{array}$ & $\begin{array}{l}\text { Setelah } \\
\text { Perlakuan } \\
(\text { hari Ke }-18) \\
(\mathrm{GD} 3)(\mathrm{mg} / \mathrm{dl})\end{array}$ \\
\hline Kontrol(-) & $80.67 \pm 8.55$ & $254.67 \pm 56.50$ & $230.17 \pm 31.96$ \\
Kontrol(+) & $83.83 \pm 8.70$ & $255.67 \pm 40.59$ & $81.67 \pm 9.65$ \\
Kelompok1 & $83.50 \pm 8.17$ & $232.17 \pm 38.07$ & $96.17 \pm 18.09$ \\
& 87.50 & $252.33 \pm 43.45$ & $89.83 \pm 12.95$ \\
Kelompok2 & \pm 14.14 & $239.83 \pm 24.59$ & $97.33 \pm 20.50$ \\
\hline Kelompok 3 & $84.33 \pm 8.45$ & 0.000 \\
\hline $\mathrm{p}$ & 0.831 & 0.827 & 0.000 \\
\hline
\end{tabular}

GD 3 pada kontrol negatif mengalami sedikit penurunan kadar glukosa darah dibandingkan GD2, sedangkan pada kontrol positif, kelompok 1, kelompok 2, dan kelompok 3 mendapatkan nilai rata-rata glukosa darah yang hampir sama.

Selanjutnya dilakukan Post Hoc Test untuk mengetahui tingkat signifikansi penurunan kadar glukosa darah pada masingmasing kelompok perlakuan. Hasil Post Hoc Test dapat dilihat pada tabel 2. Terdapat perbedaan yang signifikan pada rerata kadar glukosa darah kelompok kontrol (-) dengan kontrol (+), kelompok 1, kelompok 2, kelompok 3. Rerata kadar glukosa darah kelompok kontrol (+) tidak menunjukkan perbedaan yang signifikan dengan kelompok 1, kelompok 2, kelompok 3.Rerata kadar glukosa darah kelompok 1 kelompok 2, kelompok 3tidak menunjukan perbedaan yang signifikan.

\section{PEMBAHASAN}

Pemberian tahu yang difermentasi dengan Rhizopus sp. mampu menurunkan kadar glukosa darah karena kaya serat, protein, isoflavon, lemak, dan asam amino ${ }^{12}$. Serat yang terkandung dalam produk olahan kedelai antara lain adalah pektin dan arabinogalaktan ${ }^{13}$. 

norvegicus)

Tabel 2. Hasil Post Hoc Test Kadar Glukosa Darah Tikus Putih (Rattus norvegicus)

\begin{tabular}{llll}
\hline $\begin{array}{l}\text { Kelompok } \\
(\mathrm{I})\end{array}$ & $\begin{array}{l}\text { Kelompok } \\
(\mathrm{J})\end{array}$ & $\begin{array}{l}\text { Mean } \\
\text { Difference } \\
(\mathrm{I}-\mathrm{J})\end{array}$ & $\mathrm{p}$ \\
\hline Kontrol (-) & Kontrol (+) & 148.50 & 0.001 \\
& Kelompok 1 & 134.00 & 0.001 \\
& Kelompok 2 & 140.33 & 0.001 \\
& Kelompok 3 & 132.83 & 0.001 \\
Kontrol (+) & Kelompok 1 & -14.50 & 0.224 \\
& Kelompok 2 & -8.17 & 0.489 \\
& Kelompok 3 & -15.67 & 0.190 \\
Kelompok 1 & Kelompok 2 & 6.33 & 0.591 \\
& Kelompok 3 & -1.17 & 0.921 \\
Kelompok 2 & Kelompok 3 & -7.50 & 0.525 \\
\hline
\end{tabular}

Pektin merupakan polisakarida larut air yang dapat melewati begitu saja pencernaan enzimatik di dalam usus halus ${ }^{14}$. Pektin akan didegradasi di kolon oleh mikroflora kolon dan membentuk gel yang pekat sehingga sulit untuk diabsorbsi sehingga secara menghambat kenaikan kadar glukosa darah $^{15}$. Arabinogalaktan dan galaktomanan juga terdapat di dalam kedelai dan berperan menghambat penyerapan glukosa di dalam usus $^{13}$.

Pembentukan gel pekat oleh polisakarida larut air menghambat pelepasan hormon incretindalam usus dan mengurangi kebutuhan insulin. Polisakarida dalam bentuk gel juga akan memperlama waktu penyerapan, sehingga tubuh dapat mempertahankan kadar glukosa dari jaringan untuk tetap teratur dan tidak langsung melonjak ${ }^{16}$. Polisakarida larut air juga merangsang tubuh mengeluarkan Glucose-dependent Insulinotropic Polypeptide (GIP) yang dapat mempercepat respon insulin untuk mempercepat penurunan kadar glukosa dalam darah. GIP juga mengurangi penyimpanan trigliserida di dalam hati secara tidak langsung melalui hormon turunan adiponektin sehingga dapat menaikkan sensitivitas dari insulin ${ }^{17}$.
Bagian dari serat yang tidak dapat dicerna dengan baik di dalam usus halus akan mengalami fermentasi di dalam usus besar atau colon, misalnya selulosa. Fermentasi tersebut menghasilkan asam-asam lemak rantai pendek jenis asetat, propionat, dan butirat yang akan diserap kembali menuju aliran darah ${ }^{18}$. Asetat diketahui dapat menurunkan asam lemak bebas di dalam darah yang dapat menghambat proses utilisasi glukosa di jaringan dan memperburuk resistensi insulin. Propionat diketahui dapat meningkatkan sekresi insulin ${ }^{19}$.

Produk olahan kedelai mengandung protein antara lain arginin dan glisin yang dapat meningkatkan sensitivitas insulin ${ }^{10}$. Arginin berfungsi untuk memperkuat sekresi insulin hingga dua kali lipat dalam keadaan hipoglikemik serta meningkatkan transport glukosa dari darah ke dalam hati, otot, dan jaringan lain dan menyebabkan penurunan kadar glukosa darah ${ }^{11}$.

Kedelai juga mengandung isoflavon sebagai antioksidan untuk memperbaiki jumlah massa sel beta pankreas yang telah mengalami kerusakan oksidatif akibat keadaan hiperglikemia ${ }^{20}$. Hiperglikemia memicu terjadinya pemendekan telomer sehingga terjadi penuaan dini dan menginduksi terjadinya degenerasi sel beta pankreas $^{21}$. Genistein merupakan salah satu isoflavon dalam kedelai yang dapat melindungi sel beta pankreas terhadap DNA strand breaks akibat radikal bebas dan stres oksidatif sehingga tidak terjadi kematian sel beta pankreas ${ }^{22}$.

Tahu yang difermentasi dengan Rhizopus sp. juga mengandung asam omega ${ }^{9}$. Asam omega-3 dalam tahu yang difermentasi dengan Rhizopus sp. mampu meningkatkan uptake glukosa di membran sel otot rangka dengan menaikkan jumlah GLUT4 pada membran plasma sel otot rangka. Peningkatan GLUT4 akan meningkatkan glucose-6phospate yang akan memicu kenaikan sintesis glukosa ke dalam otot rangka ${ }^{23}$. 


\section{KESIMPULAN}

Tahu yang difermentasi dengan Rhizopus sp.mampu menurunkan kadar glukosa darah tikus putih (Rattus norvegicus) yang diinduksi Alloxan.

\section{UCAPAN TERIMA KASIH}

Ucapan terimakasih dihaturkan kepada Drs. Widardo, M.Sc yang telah memberikan kritik yang membangun hingga dapat terselesaikannya naskah publikasi ini.

\section{DAFTAR PUSTAKA}

1. Mihardja L. Faktor yang berhubungan dengan pengendalian gula darah pada penderita diabetes mellitus. Majalah Kedokteran Indonesia 2009; 59 (9): 418 424.

2. Suyono S. Diabetes melitus di Indonesia. Dalam: Sudoyo AW, Setiyohadi B, Alwi I, Simadibrata M., Setiasti S,editor. Buku IlmuPenyakit Dalam Jilid 3 Edisi 5. Jakarta: Departemen Ilmu Penyakit Dalam Fakultas Kedokteran Universitas Indonesia, 2009: 1877.

3. Waspadji S. Diabetes melitus, penyulit kronik dan pencegahannya. Jakarta: Balai penerbit FKUI; 2009.

4. Edwina DA, Manaf A, Efrida. Pola komplikasi kronis penderita diabetes melitus tipe 2 rawat inap di bagian penyakit dalam RS. Dr. M Djamil Padang Januari 2011 - Desember 2012. Jurnal Kesehatan Andalas2015; 4 (1): 102 - 206.

5. Lestari DD, Purwanto D, Kaligis S. Gambaran kadar glukosa darah puasa pada mahasiswa angkatan 2011 fakultas kedokteran universitas sam ratulangi dengan indeks massa tubuh 18,5-22,9 $\mathrm{kg} / \mathrm{m} 2$. Jurnal e-Biomedik (eBM)2013; 4 (2): 991 - 996.

6. Perkumpulan Endokrinologi Indonesia(PERKENI). Konsensus pengelolaan dan pencegahan diabetes mellitus tipe 2 di Indonesia 2006. Jakarta: PERKENI; 2006.

7. Harum A, Larasati TA, Zuraida R. Hubungan diet serat tinggi dengan kadar $\mathrm{HbA1c}$ pasien diabetes mellitus tipe 2 di RSUD Abdul Moeloek provinsi Lampung. Medical Journal of Lampung University 2013; 2 (4): $79-87$.

8. Permatasari A. Uji efek penurunan kadar glukosa darah ekstrak etanol 70\% buah jambu biji pada kelinci jantan lokal [Skripsi]. Surakarta: Universitas Muhammadiyah Surakarta; 2008.

9. Sudaryantiningsih C. Analisis kandungan asam linoleat dan linolenat tahu kedelai dengan rhizopus oryzae dan rhizopus oligosporus sebagai koagulan[Thesis]. Surakarta: Universitas Negeri Sebelas Maret.; 2009.

10. Anderson JW. Diabetes Mellitus Modern Nutrition in Health and Disease 2 10th edition. USA : Lippincott Williams and Wilkins; 2006. Hal 1043-66.

11. Rahadiyanti A. Pengaruh tempe kedelai terhadap kadar glukosa darah pada prediabetes[Skripsi].Semarang: Universitas Diponegoro; 2011.

12. Jooyandeh H. Soy products as healthy and functional foods. Middle-East Journal of Scientific Research 2011; 7 (1): 71-80.

13. Sada N, Tanko Y, Mabrouk M. Effect of soya beans supplement on blood glucose level and haematological indices on alloxan induced diabetic wistar rats. Annals of Biological Research2013; 4 (2): 208 - 213.

14. Sizer F, Whitney E. Nutrition: Concepts and Controversies. Edisi 11. New York: Belmont CA; 2008. 
15. Weickert MO, Pfeiffer AFH. Metabolic effects of dietary fiber consumption and prevention of diabetes. Journal of Nutrition2008; $138: 439-442$.

16. Wong JMW, Jenkins DJA. Carbohydrate digestibility and metabolic effects. Journal of Nutrition2007;137 (11) : 2539 $-2546$.

17. Weickert MO, Pfeiffer AF. Signalling mechanisms linking hepatic glucose and lipid metabolism. Diabetologia2006; 49 : 1732-1741.

18. Backhed F, Manchester JK, Semenkovich CF, Gordon JI. Mechanisms underlying the resistance to diet-induced obesity in germ-free mice. National Accademy of Science USA 2007; 104 : 979-984.

19. Fitri RI, Yekti W. Hubungan konsumsi karbohidrat, konsumsi total energi, konsumsi serat, beban glikemik dan latihan jasmani dengan kadar glukosa darah pada pasien diabetes mellitus tipe 2 . Journal of Nutrition and Health Science 2014; 2 (3).

20. Lu M, Wang R, Song $X$, Chibbar R, Wang X, Wu L, Meng QH. Dietary soy isoflavones in rease insulin secretion and prevent the development of diabetic cataracts in streptozotocin-induced diabetic rats. Nut Res2008; 28 (7) : 464 471.

21. Mustofa MS, Mukhtar D, Susmiarsih T, Royhan A. Pengaruh Kedelai (Glycine max (L) Merril terhadap kadar glukosa darah dan ekspresi insulin sel B Pankreas pada tikus diabetik. Jurnal Kedokteran Yarsi2010; 18 (2): 094-103.

22. Choi MS, Jung UJ, Yeo J, Kim MJ and Lee MK. Genistein and daidzein prevent diabetes onset by elevating insulin level and altering hepatic gluconeogenic and lipogenic enzyme activities in non-obese (nod) mice. Diabetes Metabolism 2008;2 (24) : $74-81$.

23. Caterina RD, Madonna R, Bertolotto A, Schmidt EB. N-3 fatty acids in the treatment of diabetic patients. Diabetes Care2007; 30 (4) : 1012 1026. 